\title{
Carbon stock in forest aboveground biomass - comparison based on Landsat data
}

\author{
Vilém Pechanec ${ }^{1 *}$, Filip Stržínek ${ }^{1}$, Jan Purkyt ${ }^{2,3}$, Lenka Štěrbová2, Pavel Cudlín² \\ ${ }^{1}$ Palacký University Olomouc, Department of Geoinformatics, 17. listopadu 50, CZ - 77146 Olomouc, Czech Republic \\ ${ }^{2}$ Global Change Research Institute AS CR, Lipová 9, CZ - 37005 České Budejjovice, Czech Republic \\ ${ }^{3}$ University of South Bohemia in České Budějovice, Faculty of Agriculture, Studentská 1668, \\ CZ-370 05 České Budějovice, Czech Republic
}

\begin{abstract}
The objective of this study was to verify a possibility of the assessment of carbon stock above all in forest aboveground biomass in the area of Czech Republic based on Landsat data and terrestrial mapping of land cover. Landsat 7 ETM+ data and method based on vegetation index ND45 were used. Simultaneously the aboveground carbon stock was assessed by expert based estimations of carbon in aboveground biomass in the various classes of landscape cover, derived from Corine Land Cover 2012 data. By comparison of results obtaining by both methods for the whole investigated area in the Czech Republic the differences reached only $4.68 \%$ and for forest stands $7.19 \%$. The results of aboveground carbon stock based on the Landsat $7 \mathrm{ETM}+$ data did not differ distinctly from the assessment of carbon stock for individual classes of land cover for both vegetation cover of the Czech Republic and forest stands.
\end{abstract}

Key words: aboveground biomass; carbon stock; remote sensing data; vegetation indices; Czech Republic

Editor: Bohdan Konôpka

\section{Introduction}

Carbon naturally occurs in many forms. In connection with the climate change carbon dioxide $\left(\mathrm{CO}_{2}\right)$ is the mostimportant form of carbon and its fixation in chemical compounds has got an important role. $\mathrm{CO}_{2}$ in the line with methane, dinitrogen dioxide, sulphate fluoride, water vapour and some other gases are generally marked as greenhouse gases which actively participate on the global climate change. On the first sight the change is mainly linked with increasing of temperature. In the last 100 years the average temperature has increased by $0.74^{\circ} \mathrm{C}$ (Marek et al. 2011). According to prediction value of carbon dioxide will reach the limit of $400 \mathrm{ppm}$ very soon (Stocker et al. 2013). It is obvious that this phenomenon has been influenced by human activity, mainly due to combustion of fossil fuels and deforestation of tropical forests (Cudlín et al. 2013).

The Czech Republic extends on the area of $78866 \mathrm{~km}^{2}$. Forest ecosystems cover $29076 \mathrm{~km}^{2}$, i.e. $36.9 \%$ of the whole area of the Czech Republic. Approximately coniferous forests cover $60 \%$ of the whole area and deciduous forests $40 \%$. Total timber reserve is about 934 mil. $\mathrm{m}^{3}$ (Vašíček 2015). Up to 45\% of the whole terrestrial carbon is fixed in forests (Oulehle et al. 2011). These days scientists have focused on the carbon quantification in ter- restrial ecosystems and biomass in a different time span. Many studies have been engaged in a question how to assess carbon content by the most simple and exact way.

Assessment of carbon stock in aboveground biomass has been worked out by methods based on both direct measurement and remote sensing (RS) approaches. Methods based on contact measurements always provide the most accurate results but they are highly finance and time consuming (Brown 2002; Coomes et al. 2002; Gibbs et al. 2007; Machar et al. 2016). Satellite or radar data have got great potential for determination of vegetation carbon content. Moreover in inaccessible areas they are the only possibility how to find out the carbon content in vegetation cover. This is the reason why many research studies have been focused on improved carbon assessment using remote sensing methods (Goodenough et al. 2005; Vicharnakorn et al. 2014; Mandal \& van Laake 2005).

Basic methods of contact approach are forest inventory, method of production tables and eddy covariance method. Forestry inventory is greatly widespread way of assessment of biomass and carbon stock on the base of parameters realized during ground survey (Brown \& Schroeder 1999; Jenkins et al. 2004; Zhang et al. 2012). Ponce-Hernandez (2004) described in detail the principal 
of tree allometry in connection with carbon measurement in biomass. Main-Knorn et al. (2011) compared carbon stock assessed by forest inventory with figures derived on the base of satellite data analysis. Method of production tables, used in the frame of IPCC programme, is based on a link of individual classified categories and prepared values on carbon stock or production, derived from previous contact measurements and literary knowledge. This simple method is implemented by several models e.g. InVEST or NLLUF-KP10 (Cruickshank et al. 2000; Kareiva et al. 2011; Kuldeep 2011; Sanga-Ngoie et al. 2012). Eddy covariance method is based on the direct measurement of $\mathrm{CO}_{2}$ flows in the frame of ecosystem stations. The method is very precise, but it measures only direct $\mathrm{CO}_{2}$ flow on small areas (Hunt et al. 2002; Zhang et al. 2012).

Remote sensing can be used for the assessment of carbon stocks by two available means. First one is an assessment of aboveground biomass from that selected eco-physiological parameters (e.g. gross primary production, net primary production, photosynthetically active radiation) are derived and carbon quantity is calculated (Field et al. 1995; Patenaude et al. 2005; Awange \& Kyalo Kiema 2013; Pechanec et al. 2014). The second one is a land cover mapping and derivation of basic characteristics (type, spatial distribution and pattern) of its categories and to combine these data with ground forest inventory (Pachavo \& Murwira 2014; Iizuka \& Tateishi 2015; Zheng et al. 2008).

The aim of this study was to propose some method based on RS data for the assessment of carbon stock of forest aboveground biomass on the territory of the Czech Republic.

\section{Material and methods}

\subsection{Expert data of carbon stock}

In accordance with the basic IPCC methodology of carbon stock assessment (Kuldeep 2011; Sanga-Ngoie et al. 2012) expert estimation of carbon stock values has been performed for vector data layer of the most detailed level 3 of individual land cover classes of Corine Land Cover (Corine LC). Particular land cover categories were divided according the presence/absence of natural and near to nature habitats (Chytrý et al. 2010) according to the Habitat mapping layer provided by the Nature Conservation Agency of the Czech Republic (NCACR 2014). Proportional representation of non-natural habitats in the territory not covered by the layer of Habitat mapping was estimated using analyses of land use and carbon content on $450 \times 450 \mathrm{~m}$ plots in the grid $7 \times 7 \mathrm{~km}$, made by IFER ltd. in the frame of CzechTerra project (Šímová et al. 2009). The values of carbon stock of aboveground biomass of individual 193 natural, near to nature and non-natural habitats (Seják et al. 1993) were derived from literature (Stará et al. 2011). The carbon values for each Corine LC class were ultimately determined by means of the carbon values of natural and non-natural habitats weighted by their average distribution in the Corine LC classes in the whole territory of the Czech Republic.

\subsection{Satellite Landsat 7 ETM+ images}

Data were acquired by means of the Earth Explorer tool (http://earthexplorer.usgs.gov/). For the territory of the Czech Republic there were selected 9 images of Landsat 7 ETM+ from 20. 5. 2012 to 11.7.2015. Date and cloudiness coverage percentage were the key factors for the selection of images. The basic condition was vegetation period, i.e. period from May to October. Mostly there were selected images from the years 2013-2015 because of small cloudiness and other meteorological conditions. Only one image had to be selected from the year of 2012. The list of all images used for an assessment of carbon stock is displayed in the Table 1.

\subsection{Satellite data procedure}

\section{Cloudiness masking}

Because of not all images were obtained without cloudiness and there were not other better images, there was necessary to mask cloudiness on three images with ID LE71910252013168ASN00, LE71920262014162ASN00 and LE71900262015183NSG00.

We use CALCULATE CLOUD MASK USING FMASK tool, which is avalaible in ENVI software. Total area under cloudiness mask covered the area of 32760 hectares. The results of masking are seen on Fig. 1.

Table 1. Applied satellite Landsat 7 images of sensor ETM+ covering the whole territory of the Czech Republic for aboveground carbon stock assessm.

\begin{tabular}{|c|c|c|c|c|c|c|}
\hline & ID & Date & WRS path & WRS row & Cloudiness [\%] & Format \\
\hline 1 & LE71930252015156NSG00 & 5.6 .2015 & 193 & 25 & 0 & \\
\hline 2 & LE71920252012141ASN00 & 20.5 .2012 & 192 & 25 & 0 & \\
\hline $3 *$ & LE71910252013168ASN00 & 17. 6.2013 & 191 & 25 & 18 & \\
\hline 4 & LE71900252015183NSG00 & 2.7 .2015 & 190 & 25 & 8 & \\
\hline 5 & LE71890252013202ASN00 & 21.7 .2013 & 189 & 25 & 0 & GEOTIFF \\
\hline $6 *$ & LE71920262014162ASN00 & 11. 6.2014 & 192 & 24 & 1 & \\
\hline 7 & LE71910262013168ASN00 & 17.6.2013 & 191 & 24 & 0 & \\
\hline $8 *$ & LE71900262015183NSG00 & 2.7 .2015 & 190 & 24 & 3 & \\
\hline 9 & LE71890262015192NSG00 & 11.7.2015 & 189 & 24 & 0 & \\
\hline
\end{tabular}

Symbol * indicates images with mask by reason of cloudiness. 

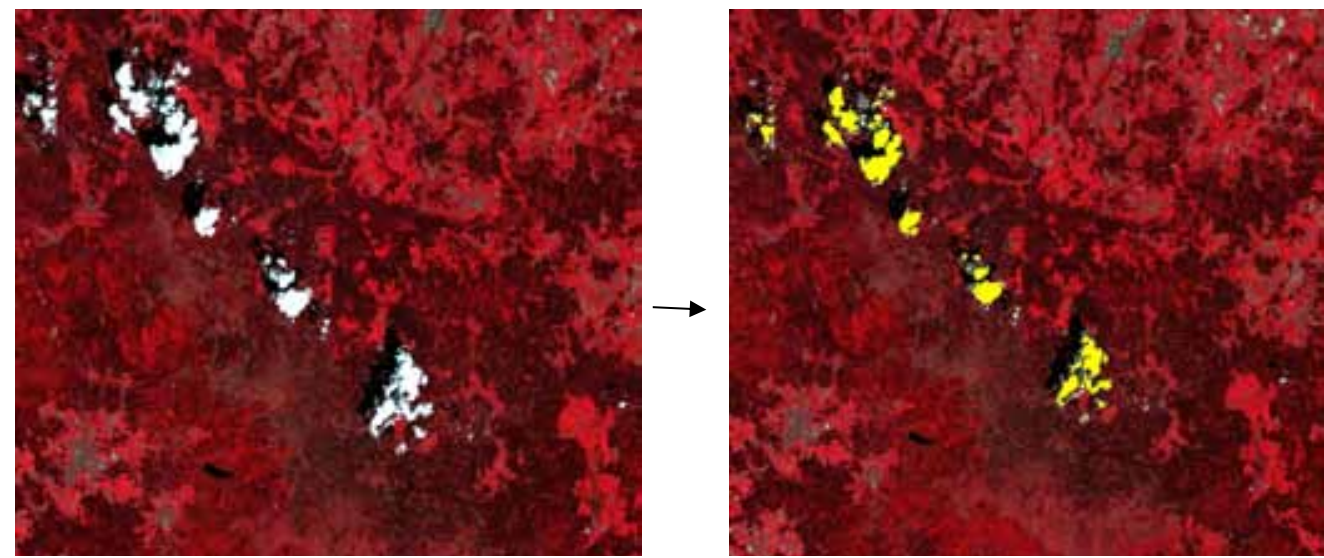

Fig. 1. Final cloudiness mask on the image No. 6 with ID LE71920262014162ASN00 (source: own/personal processing).

Mosaic framing and mosaic trimming for the territory of the Czech Republic

For unified processing of all 9 images their mosaic using the ENVI software (SEAMLESS MOSAIC tool) was carried out. The outputs of this process are pictured on Figs. 2 and 3.
Radiometric and atmospheric corrections of Landsat 7 images

Images from satellites Landsat 7 and 8 dispose of automatic radiometric, geometric and altitudinal corrections at the Level 1T. For next level of atmospheric and radiometric corrections there is necessary to utilize infor-

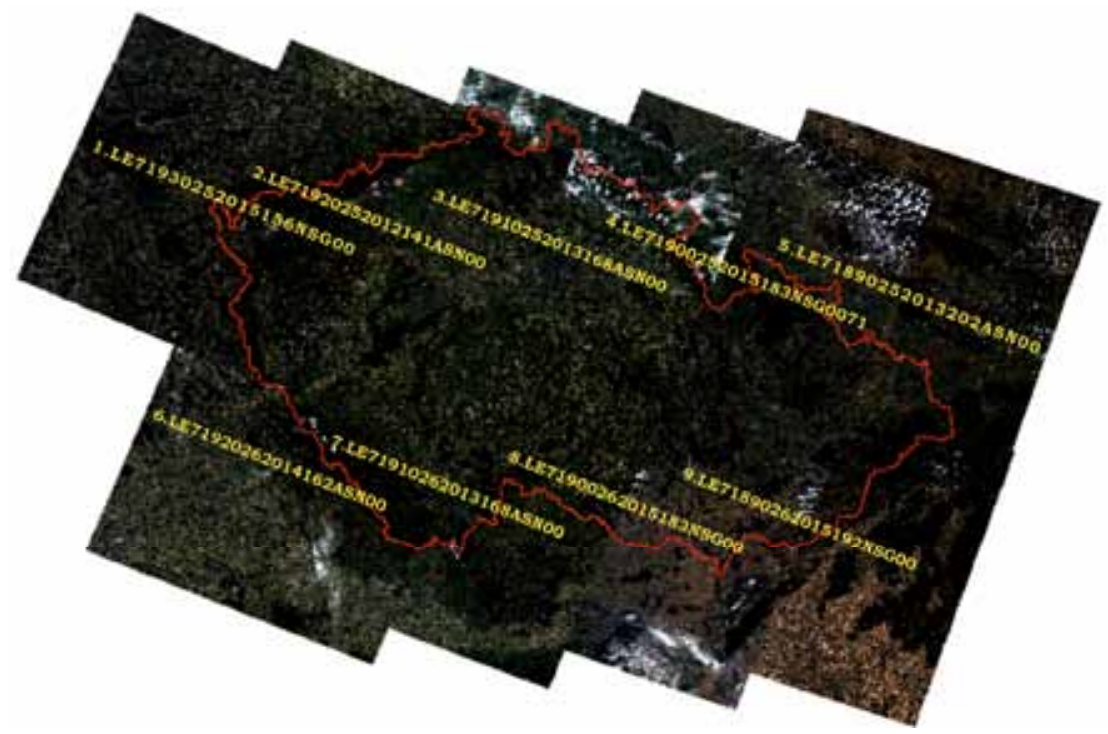

Fig. 2. Outputs of the mosaic process (source: own/personal processing).

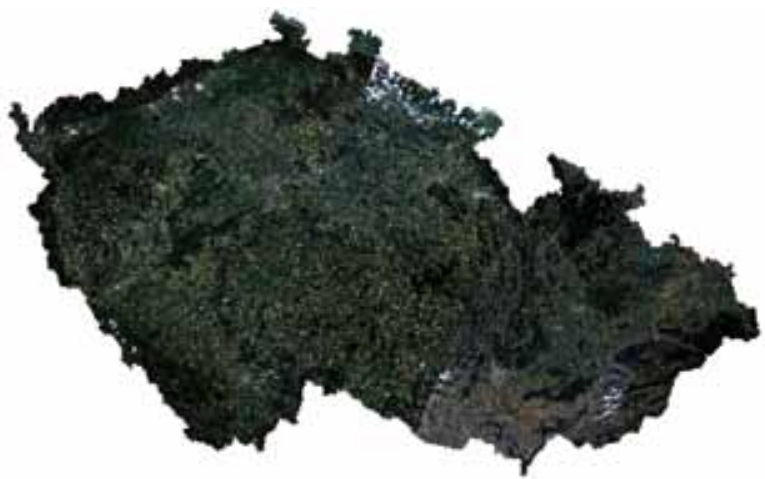

Fig. 3. Trimmed edges of 9 satellite images of the Czech Republic (source: own/personal processing).

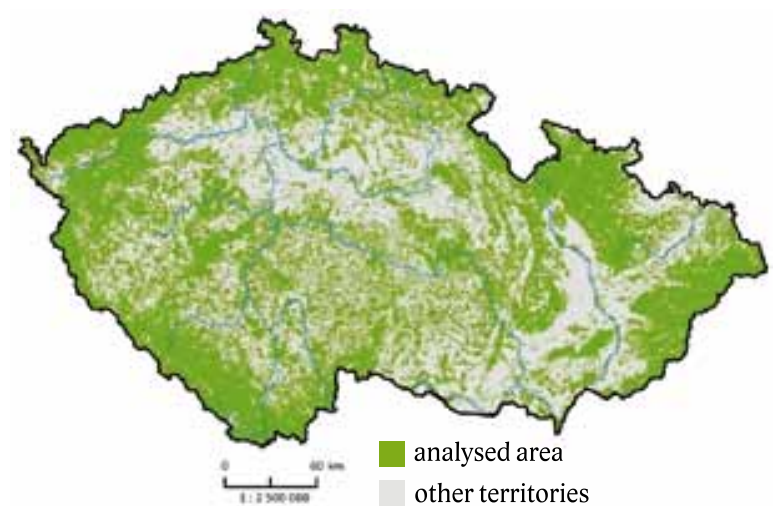

Fig. 4. Final area map delimitated for the assessment of carbon stock of an area of the Czech Republic. 
Table 2. Calculation by method based on the ND45 index.

\begin{tabular}{llc}
\hline \multicolumn{1}{c}{ Application } & \multicolumn{1}{c}{ Formula } & 1 \\
\hline Generally & ND45 $=128 \times[(\mathrm{TM} 4-\mathrm{TM} 5) /(\mathrm{TM} 4+\mathrm{TM} 5)]+128$ & 2 \\
Band Math & ND45 $=(128 \times((\mathrm{float}(\mathrm{b} 1)-\mathrm{b} 2) /(\mathrm{float}(\mathrm{b} 1)+\mathrm{b} 2))+128)$ & 3 \\
Calculation of carbon stock & Biomass $\left[\mathrm{kg} \mathrm{ha}^{-1}\right]=-478.58+4.5041 \times \mathrm{ND} 45$ & 4 \\
Calculation of carbon stock & Carbon $\left[\mathrm{kg} \mathrm{ha}^{-1}\right]=$ biomass $\times$ volume wood density $\left(400 \mathrm{~kg} \mathrm{~m}^{-3}\right) \times 0.5$ & 4 \\
\hline
\end{tabular}

mation on a specific image from the text metadata file. Since a pixel value is represented after data download by so called digital number (DN) which is not suitable for quantitative picture analyses, it is necessary to transpose it to calibrated value of the real image reflectance. This operation is generally called radiometric calibration or correction. This process was performed using ENVI programme by means of the Radiometric Calibration with the output TOA - Top of Atmosphere Reflectance. Then atmospheric calibration was carried out using ENVI software by Dark Subtraction, Quick Atmospheric correction (QUAC) (Shippert 2013).

\section{Banding elimination of Landsat 7 images}

Regarding to the decrease of image quality of Landsat 7 by systematic error in consequence of SLC disturbance in the year of 2003, an image radiometric defect had to be removed. This process was performed with the help of ENVI software using Fourier transformation.

\section{Calculation of the aboveground carbon stock by means} of the ND45 index

Calculation of aboveground carbon stock was done by means of the ND45 index (Goodenough et al. 2005) using the Band Math tool (ENVI software). The method consists in an assessment of aboveground biomass on the base of spectral vegetation index ND45. Assessed biomass is then recounted to carbon stock ( $\mathrm{kg} \mathrm{C}$ per hectar). Mathematical notation is described in the Table 2.

Calculation of carbon stock was applied for the selected areas of the Czech Republic $\left(43841 \mathrm{~km}^{2}\right)$ after subtraction of a) areas of masked cloudiness and b) categories with lowvegetation cover (e.g. built-up area) (see Table 3). The plots were spatially defined on the base of land cover class level 3 of the Corine LC 2012 (see Fig. 4).

\section{Calculation of aboveground carbon stock with use of expert assessment}

For the assessment of carbon stock of aboveground biomass by means of expert estimations, the same Corine LC 2012 data layer was used. This layer was then segmented according the presence of natural and non-natural habitats. These segments were attributed by average expert carbon stock values $\left(\mathrm{t} \mathrm{ha}^{-1}\right)$ of aboveground biomass in individual Corine LC classes, containing and non containing natural habitats. Real carbon stock was then calculated.

To obtain carbon stock of aboveground biomass in forest stands the area of broadleaved, coniferous and mixed forests (TAG 311, 312, 313) according to Corine LC 2012 was determined. The Corine LC forest classes were then assigned expert based carbon values per ha. The carbon stock values determined by method of ground observation and derived from remote sensing data were compared.

Table 3. Land cover classes in the Czech Republic according Corine LC 2012. Symbol * is for categories of higher percentage of vegetation cover.

\begin{tabular}{llc}
\hline TAG-level3 & \multicolumn{1}{c}{ Landuse category } & Area $\left[\mathrm{km}^{2}\right]$ \\
\hline 111 & Continuous build-up area & 15.7 \\
112 & Discontinuous build-up area & 3828 \\
121 & Industrial and commercial zones & 631.3 \\
122 & Public road and railway system & 72 \\
123 & Ports & 0.8 \\
124 & Airports & 48.7 \\
131 & Mining areas & 170 \\
132 & Dumps & 79.4 \\
133 & Building sites & 10.9 \\
$141^{*}$ & Urban green areas & 67 \\
142 & Sports and recreational areas & 173.3 \\
211 & Non-irrigated arable land & 28998 \\
$221^{*}$ & Vineyards & 164 \\
$222^{*}$ & Orchards, hop-fields and garden plantations & 294 \\
$231^{*}$ & Meadows and pastures & 7946 \\
$242^{*}$ & Mixture of meadows, fields and steady fields & 473 \\
$243^{*}$ & Agricultural areas with natural vegetation & 7116 \\
$311^{*}$ & Broadleaved forests & 2839 \\
$312^{*}$ & Coniferous forests & 17129 \\
$313^{*}$ & Mixed forests & 6339 \\
$321^{*}$ & Natural meadows & 257 \\
$322^{*}$ & Steppes and bushes & 19 \\
$324^{*}$ & Underbrush in forests & 1527 \\
332 & Rocks & 1.7 \\
$333^{*}$ & Areas with low density vegetation & 1.5 \\
411 & Marshes and swamps & 60.6 \\
412 & Peatbogs & 46 \\
511 & Water flows & 46.3 \\
512 & Water sheets/areas & 530.4 \\
\hline & & \\
& &
\end{tabular}

\section{Results}

The results of carbon stock calculation on the investigated territory of the Czech Republic $\left(43,841 \mathrm{~km}^{2}\right)$, using the method based on the ND45 index, were comparable with expert assessment. Calculated carbon stocks of aboveground biomass in the Czech Republic using ND45 method was $277,842,483$ tons, according to expert production table $265,418,848$ tons. Values of the carbon stock for the investigated area differed only by $4.68 \%$.

For the assessment of carbon stock of aboveground biomass in forest stands the areas of occurrence of Corine LC 2012 classes (conifer, broadleaved and mixed forests) on the territory of the Czech Republic were summarized and the carbon stock of aboveground biomass was computed according to the expert assessment of carbon values for individual classes. The area used to find out the carbon stock from remote sensing data had to be reduced by area covered by cloudiness and therefore it differed from the total forest area (Table 4). 
Table 4. Carbon stock of aboveground biomass in the forest area of the Czech Republic (source: own/personal processing).

\begin{tabular}{lcc}
\hline \multirow{2}{*}{ Category } & \multicolumn{2}{c}{ Carbon stock [t] } \\
\cline { 2 - 3 } & ND45 method & Expert assessment \\
\hline Broadleaved forests & $21,727,584$ & $24,667,514$ \\
Coniferous forests & $135,936,161$ & $164,123,993$ \\
Mixed forests & $48,534,471$ & $55,968,486$ \\
Forests - total & $206,198,216$ * & $244,759,992^{* *}$ \\
\hline * for the total area of $24517 \mathrm{~km}^{2}$; ** for the total area of $27009 \mathrm{~km}^{2}$.
\end{tabular}

In the case of entire forest stands there was stated the difference of $7.19 \%$. Difference for broadleaved forests was $2.97 \%$, coniferous forests $8.75 \%$ and mixed forests $4.47 \%$ in comparison with results obtained by expert assessment. On the base of results we can presume that the method based on ND45 index is suitable for the assessment of above ground carbon stock on the territory of the Czech Republic.

\section{Discussion}

The assessment of carbon stock of aboveground biomass from RS data seems to be applicable but we should critically discus not only data processing but also the comparative expert based values. The calculation of aboveground carbon stock was based on biomass estimation by means of the ND45 index. This method belongs to the most frequent if multispectral data are used (Cruickshank et al. 2000); in the case of hyperspectral data, approaches based on LAI index (Liang et al. 2012) or fAPAR index (Hunt et al. 2002) are prevailing. The crucial problem of used approach is the selection of vegetation index; the most frequently used NDVI index has serious problems with the saturation effect at higher biomass values (Sanga-Ngoie et al. 2012). Another frequently used approach based on biomass empirical models works unfortunately only with one picture from main vegetation phase which causes a lot of inaccuracies. The seasonal NDVI index derived from time series could be one of a suitable solution (Zhu \& Liu 2014). According to their results NDVI index has stronger relationship with aboveground biomass in the autumn compared to main growing season.

Another aspect influencing the selection of suitable vegetation index is a structure and amount of analyzed vegetation; forests in different vegetation zones differ strongly in their vegetation structure. Therefore we analyzed a couple of indices (Goodenough et al. 2005; Zheng et al. 2008) and selected ND45 index, derived on two localities in Canada with tree species composition, dominant spruce and pine species (Goodenough et al. 2005), relatively similar to our dominant tree species.

The method based on ND45 indicator has been selected as optimal for the assessment of carbon stock of aboveground vegetation by means of RS tools after previous testing on a smaller area of $450 \mathrm{~km}^{2}$. The very important role is played by an input value - volume wood density. For the assessment of carbon stock in the Czech Republic there was set value of $400 \mathrm{~kg} \mathrm{~m}^{-3}$ considering extent and land cover categories of studied area. Using value differentiation according to landscape cover categories could lead to further refinement of the results.

Expert based values of aboveground carbon stock were constructed as a medium value for a given habitat type under conditions of the Czech Republic. It means that this coefficient does not reflect an actual state of an individual habitat, given by above all its health status and age structure. Due to this fact the values obtained by means of the method based on mean ND45 index could provide sufficient information about actual mean state of aboveground biomass.

Only few publications have presented a comparison between carbon computation from remote sensing data and expert estimation. The results of one of them, reporting 4\% difference using NDVI index (Sanga-Ngoie et al. 2012), are very similar to our results.

In this paper it was mentioned that the real values of reflectance must be available for the quantitative image analysis. Input units of TOA reflectance were used for the assessment of carbon crop, it means radiometrically calibrated DN values according specific factors (e.g. sun elevation) for each image. Unfortunately, atmospheric influences have not been removed from these data. There were undertaken some tests to remove atmospheric influences using method of Dark Subtraction but obtained results of reflectance were evaluated as unsuitable. Improper removing of atmospheric influences could slightly affect obtained stock values. In a new version of the ENVI software more advanced tools for removing of atmospheric influences - QUAC and FLAASH modules have been implemented but they were not accessible to authors at that time.

\section{Conclusion}

The aim of this study was to propose some method based on RS data for the assessment of carbon stock of forest aboveground biomass on the territory of the Czech Republic. Comparison of results of aboveground carbon stock computation by RS method based on ND45 index with results obtained by the expert assessment showed that less time consuming RS method is applicable for bigger areas. Values of the carbon stock for the entire valuated area differed only by $4.6 \%$, for forest area the differences ranged from $2.97 \%$ to $8.76 \%$ according to the forest category. The results of RS method proved to be comparable with methods of ground observation that are often expensive and time consuming. Moreover ground observation methods are not applicable in inaccessible areas. In addition, information about aboveground biomass carbon stock in the Czech Republic in 2012 can be compared in future with up-to-date values to monitor changes in carbon storage. 


\section{Acknowledgement}

This work was supported by grant from Iceland, Liechtenstein and Norway [grant number EHP-CZ02-OV-1-014-2014y], by the Grant Agency of Czech Republic [grant number 16-21053S] and by the Ministry of Education, Youth and Sports of CR within the National Sustainability Program I (NPU I), grant number LO1415. Authors thank to Dr. Chobot from the Nature and Landscape Conservation Agency of the Czech Republic for providing habitat mapping data.

\section{References}

Awange, J., Kyalo Kiema, J. B., 2013: Environmental geoinformatics. Monitoring and management. New York, Springer, 533 p.

Brown, S., Schroeder, P. E., 1999: Spatial patterns of aboveground production and mortality of woody biomass for eastern US forests. Ecological Applications, 9:968-980.

Brown, S., 2002: Measuring carbon in forests: current status and future challenges. Environmental Pollution, 116:363-372.

Chytrý, M., Kučera, T., Kočí, M., Grulich, V., Lustyk, P. (eds.), 2010: Katalog biotopů České republiky. 2. ed. Praha, Agentura ochrany př́rody a krajiny ČR, 445 p.

Coomes, D. A., Allen, R. B., Scott, N. A., Goulding, C., Beets, P., 2002: Designing systems to monitor carbon stocks in forests and shrublands. Forest Ecology and Management, 164:89-108.

Cruickshank, M. M., Tomlinson, R. W., Trew, S., 2000: Application of CORINE land-cover mapping to estimate carbon stored in the vegetation of Ireland. Journal of Environmental Management, 58:269-287.

Cudlín, P., Seják, J., Pokorný, J., Albrechtová, J., Bastian, O., Marek, M., 2013: Forest ecosystem services under climate change and air pollution. In: Matyssek, R. et al. (eds.): Climate Change, Air Pollution and Global Challenges. Oxford, Elsevier, p. 521-546.

Field, Ch. B., Randerson, J. T., Malmstrom, C. M., 1995: Global net primary production: Combining ecology and remote sensing. Remote Sensing of Environment, 51:74-88.

Gibbs, H. K., Brown, S., Niles, J. O., Foley, J. A., 2007: Monitoring and estimating tropical forest carbon stocks: making REDD a reality. Environmental Research Letters, 2:045023, 13 p.

Goodenough, D. G., Chen, H., Dyk, A., Li, J., 2005: Multisensor data fusion for aboveground carbon estimation. Proc. XXVIIIth General Assembly of the International Union of Radio Science (URSI), New Delhi, 400:1-4.

Hunt Jr.,E. R., Fahnestock, J. T., Kelly, R. D., Welker, J. M., Reiners, W. A., Smith, W. K., 2002: Carbon Sequestration from Remotely-Sensed NDVI and Net Ecosystem Exchange. In: Muttiah, R. S. (ed.): From laboratory spectroscopy to remotely sensed spectra of terrestrial ecosystems. Amsterdam, Springer, p. 161-174.
Iizuka, K., Tateishi, R., 2015: Estimation of $\mathrm{CO}_{2}$ sequestration by the forests in Japan by discriminating precise tree age category using remote sensing techniques. Remote Sensing, 7:15082-15113.

Jenkins, J. C., Chojnacky, D. C., Heath, L. S., Birdsey, R. A., 2004: Comprehensive database of diameter-based biomass regressions for North American tree species. Newtown Square, PA, U.S. Dept. of Agriculture, Forest Service, Northeastern Research Station, 45 p.

Kareiva, P., Tallis, H., Ricketts, T. H., Daily, G. C., Polasky, S., 2011: Natural capital. Theory and practice of mapping ecosystem services. Oxford, University Press, $357 \mathrm{p}$.

Kuldeep, P., 2011:Forest carbon management using satellite remote sensing techniques. A case study of Sagar district (MP). E-International Scientific Research Journal, 3:335-348.

Liang, S., Li, X., Wang, J., 2012: Advanced remote sensing. Amsterdam, Boston, Academic Press, 799 p.

Machar, I., Simon, J., Rejšek, K., Pechanec, V., Brus, J., Kilianová, H., 2016: Assessment of forest management in protected areas based on multidisciplinary research. Forests, 7:285, $16 \mathrm{p}$.

Main-Knorn, M., Moisen, G. G., Healey, S. P., Keeton, W. S., Freeman, E. A., Hostert, P., 2011. Evaluating the remote sensing and inventory-based estimation of biomass in the Western Carpathians. Remote Sensing, 3:1427-1446.

Mandal, R.A., van Laake, P., 2005: Carbon sequestration in community forests: an eligible issue for CDM (Acase study of Nainital, India). Banko Janakari, 15:53-61.

Marek, M. V. (ed.), 2011: Uhlík v ekosystémech České republiky v měnícím se klimatu. Praha, Academia, $253 \mathrm{p}$.

Muttiah, R. S. (ed.), 2002: From laboratory spectroscopy to remotely sensed spectra of terrestrial ecosystems. Amsterdam, Springer, 296 p.

NCA CR, 2014: Habitat mapping layer [electronic database]. Version 2014, Prague, Nature conservation agency of the Czech Republic.

Oulehle, F., Evans, C. D., Hofmeister, J., Krejci, R., Tahovska, K., Persson, T., Cudlin, P.etal., 2011: Major changes in forest carbon and nitrogen cycling caused by declining sulphur deposition. Global Change Biology, 17:3115-3129.

Pachavo, G., Murwira, A., 2014: Remote sensing net primary productivity (NPP) estimation with the aid of GIS modelled shotwave radiaton (SWR) in a Southern African Savanna. International Journal of Applied Earth Observation and Geoinformation, 30:217-226.

Patenaude, G., Milne, R., Dawson, T. P., 2005: Synthesis of remote sensing approaches for forest carbon estimation: reporting to the Kyoto Protocol. Environmental Science and Policy, 8:161-178. 
Pechanec, V., Vavra, A., Hovorkova, M., Brus, J., Kilianova, H., 2014: Analyses of moisture parameters and biomass of vegetation cover in southeast Moravia. International Journal of Remote Sensing, 35:967-987.

Ponce-Hernandez, R., 2004: Assessing carbon stocks and modelling winwin scenarios of carbon sequestration through land use changes. Rome, Food and Agriculture Organization of the United Nations, $156 \mathrm{p}$.

Sanga-Ngoie, K., Iizuka, K., Kobayashi, S., 2012: Estimating $\mathrm{CO}_{2}$ sequestration by forests in Oita Prefecture, Japan, by combining LANDSAT ETM+ and ALOS satellite remote sensing data. Remote Sensing, 4:3544-3570.

Seják, J., Dejmal, I., Petříček, V., Cudlín, P., Míchal, I., Černý, K. et al., 2003: Hodnocení a oceňování biotopů České republiky. Praha, Český ekologický ústav, MŽP, $422 \mathrm{p}$.

Shippert, P., 2013: Digital number, radiance, and reflectance [online] [cit. 2015-06-10]. Available from: http://www.harrisgeospatial.com/Home/NewsUpdates/ TabId/170/ ArtMID/ 735/ArticleID/13592/ Digital-Number-Radiance-and-Reflectance.aspx

Stocker, T. F., Qin, D., Plattner, G.-K., Tignor, M., Allen, S. K., Boschung, J. et al. (eds.), 2013: Climate change: The physical science basis. Contribution of Working Group I to the Fifth Assessment Report of the Intergovernmental Panel on Climate Change, Cambridge University Press, Cambridge, United Kingdom and New York, NY, USA. Available by http://www.climatechange2013.org/images/report/ WG1AR5 TS_FINAL.pdf

Šímová, P., Černý, M., Cienciala, E., Apltauer, J., Kučerová, J., Beranová, J. et al., 2009:A methodology for classifying aerial photographs within the CzechTerra landscape inventory system: a new approach to generating data for landscape analyses. Journal of Landscape Studies, 2:43-55.
Stará, L., Matějka, K., Cudlín, P., Bodlák, L., Pokorný, J., Středa, T. et al., 2011: Zásoby uhlíku ve vegetaci České republiky a modelová uhlíková bilance krajiny. In: Marek, M. V. (ed.): Uhlík v ekosystémech České republiky v měnícím se klimatu. Praha, Academia, p. 189-210.

Vašíček, J., 2015: Hlavní výstupy NIL 2. [online]. Available from: http://eagri.cz/public/web/ file/435678/ Vicharnakorn, P., Shrestha, R. P., Nagai, M., Salam, A. P., Kiratiprayoon, S., 2014: Carbon stock assessment using remote sensing and forest inventory data in Savannakhet, Lao PDR. Remote Sensing, 6:5452-5479.

Zhang, X., Zhao, Y., Ashton, M. S., Lee, X., 2012: Methods of measuring carbon in forests. In: Ashton, M. S., Tyrrell, M. L., Spalding, D., Gentry, G. (eds.): Managing forest carbon in a changing climate. Amsterdam, Springer, p. 139-164.

Zheng, D., Heath, L. S., Ducey, M. J., 2008: Spatial distribution of forest aboveground biomass estimated from remote sensing and forest inventory data in New England, USA. Journal of Applied Remote Sensing, 2:021502, $18 \mathrm{p}$.

Zhu, X., Li, D., 2014: Improving forest aboveground biomass estimation using seasonal Landsat NDVI time-series. ISPRS Journal of Photogrammetry and Remote Sensing, 102:222-231. 